\title{
Considerations of Use-Use Interactions between Macroalgae Cultivation and Other Maritime Sectors: An Eastern Baltic MSP Case Study
}

\author{
Aurelija Armoškaitè ${ }^{1,2, *}$, Ieva Bārda ${ }^{1} \mathbb{D}$, Ingrīda Andersone ${ }^{1} \mathbb{C}$, Ida Maria Bonnevie ${ }^{2} \mathbb{C}$, Anda Ikauniece ${ }^{1}{ }^{\oplus}$, \\ Jonne Kotta $^{3}$, Anneliis Kõivupuu ${ }^{3}$, Liisi Lees ${ }^{3}{ }^{-}$, Iwona Psuty ${ }^{4}{ }^{(}$, Solvita Strāke ${ }^{1}{ }^{1}$, Sandra Sprukta ${ }^{1}$, \\ Lena Szymanek ${ }^{4}$, Miriam von Thenen ${ }^{5}{ }^{\mathbb{D}}$, Lise Schrøder ${ }^{2}$ and Henning Sten Hansen ${ }^{2}$
}

check for updates

Citation: Armoškaitè, A.; Bārda, I.; Andersone, I.; Bonnevie, I.M.; Ikauniece, A.; Kotta, J.; Kõivupuu, A.; Lees, L.; Psuty, I.; Strāke, S.; et al. Considerations of Use-Use Interactions between Macroalgae Cultivation and Other Maritime Sectors: An Eastern Baltic MSP Case Study. Sustainability 2021, 13, 13888. https://doi.org/10.3390/su132413888

Academic Editor: Tim Gray

Received: 26 November 2021 Accepted: 13 December 2021 Published: 15 December 202

Publisher's Note: MDPI stays neutral with regard to jurisdictional claims in published maps and institutional affiliations.

Copyright: (c) 2021 by the authors. Licensee MDPI, Basel, Switzerland. This article is an open access article distributed under the terms and conditions of the Creative Commons Attribution (CC BY) license (https:// creativecommons.org/licenses/by/ $4.0 /)$.
1 Latvian Institute of Aquatic Ecology, 1007 Riga, Latvia; ieva.barda@lhei.lv (I.B.); ingrida.purina@lhei.lv (I.A.); anda.ikauniece@lhei.lv (A.I.); solvita.strake@lhei.lv (S.S.); sandra.sprukta@lhei.lv (S.S.)

2 Department of Planning, Aalborg University Copenhagen, 2450 Copenhagen, Denmark; idarei@plan.aau.dk (I.M.B.); lisesch@plan.aau.dk (L.S.); hsh@plan.aau.dk (H.S.H.)

3 Estonian Marine Institute, University of Tartu, 12618 Tallinn, Estonia; jonne@sea.ee (J.K.); anneliis.koivupuu@ut.ee (A.K.); liisi.lees@ut.ee (L.L.)

4 National Marine Fisheries Research Institute, 81-332 Gdynia, Poland; ipsuty@mir.gdynia.pl (I.P.); lszymanek@mir.gdynia.pl (L.S.)

5 Leibniz Institute for Baltic Sea Research Warnemünde, 18119 Rostock, Germany; miriam.thenen@io-warnemuende.de

* Correspondence: aurelija.armoskaite@lhei.lv; Tel.: +371-28159926

\begin{abstract}
With the blue economic sectors growing, marine macroalgae cultivation plays an important role in securing food and energy supplies, as well as better water quality in sustainable ways, whether alone or as part of a cluster solution to mitigate the effects of fish farming. While macroalgae cultivation exists in Europe, it is not that widely distributed yet; with increasing marine activities at sea, Maritime Spatial Planning (MSP) needs to ensure social recognition as well as social and spatial representation for such a new marine activity. This comparative case study analysis of MSPs of three eastern Baltic Sea countries explores the levels of support for the development of macroalgae cultivation in MSP and the degree of co-location options for this new and increasingly important sector. It presents new analytical ways of incorporating co-location considerations into the concept of social sustainability. The results of this study support the harmonisation of views on co-location, propose ways of using space to benefit multiple users as well as marine ecosystems, and highlight some of the key social challenges and enablers for this sector.
\end{abstract}

Keywords: maritime spatial planning; macroalgae cultivation; blue growth; use-use interactions; Baltic Sea

\section{Introduction}

It is widely acknowledged that global seafood stocks are under heavy pressure and to avoid their collapse immediate actions need to be taken. Here, marine aquaculture has often been proposed to increase global food security and human well-being, whilst relieving the pressures of consumption on wild stocks [1,2]. However, in its current form fish farming - the most widely adopted type of aquaculture-is highly resource demanding, is a source of pollution and nutrients, and leads to habitat destruction [1]. In comparison to fish farming, marine macroalgae and shellfish cultivation is considered a more sustainable way of generating raw resources for food and energy production [2]. Further, when cultivated as part of a multi-trophic aquaculture system-in combination with fish, macroalgae and shellfish-it is seen as a promising method for resolving the environmental impacts of fish farming [3]. Moreover, macroalgae farming has the potential to mitigate eutrophication effects and local effects of ocean acidification [4] in coastal 
water bodies worldwide. Low trophic aquaculture also plays an important part in the European Green Deal, as the sustainable blue economy has a central role in reducing pressure on Europe's land resources and tackling climate change effects [5-7]. Fisheries and the aquaculture sector contribute to securing all the Sustainable Development Goals (SDGs) but are at the core of SDG 13, to take urgent action to combat climate change and its impacts, as well as SDG 14, to conserve and sustainably use the oceans, seas, and marine resources for sustainable development. SDG 14, especially, has clear and important implications for fisheries and aquaculture, including targets to reduce marine pollution, protect aquatic ecosystems, minimize effects of ocean acidification [8], and develop scientific capacity relevant to fisheries [9].

Within the Baltic Sea ecosystem, nutrient loading is amongst the biggest challenges [10]. The Baltic Sea is a multi-jurisdictional water body, and decades of policy initiatives to reduce external nutrient loads have so far failed to reduce the adverse effects of eutrophication. This is primarily due to a significant internal release of legacy phosphorus $(\mathrm{P})$ and biological nitrogen $(\mathrm{N})$ fixation [11]. Macroalgae farming can offer a significant contribution to regional sustainability, by removing large quantities of the legacy nutrients.

However, as in other European seas, the marine macroalgae industry of the Baltic Sea Region (BSR) primarily relies on wild stocks [2,4]. Free-floating red algae Furcellaria lumbricalis ((Hudson) J.V. Lamouroux, 1813) has been one of the longest commercially harvested red algae in the BSR and is continued to be harvested in the Estonian marine waters to produce furcellaran, an additive used mostly by the food and pharmaceutical industries for its gelling properties [12,13]. In recent years, under the encouragement of European sustainable blue development initiatives, there has been a keen interest in commercial cultivation of F. lumbricalis in Estonia; emergence of a few commercial cultivation sites of Saccharina latissima [14] on the Swedish west coast $[4,13,15,16]$; experimental cultivation trials of Ulva species in the Gulf of Gdansk, Poland [17], Finland [18], Hjarnø Kattegat [19], and Estonia [20]; and experimental cultivation of Fucus vesiculosus (Linnaeus, 1753) and Fucus serratus (Linnaeus, 1753) in the Kiel fjord, Germany [21].

There are several challenges to commercial macroalgal cultivation in the BSR, most of which boil down to the unique environmental conditions of the Baltic, lack of technical solutions for growing macroalgae native to the Baltic Sea, regulatory and market-related barriers, and complexity of the project permitting process [2,22,23]. Consequently, the economic and environmental risks of macroalgae cultivation are unclear in the Baltic Sea, which stunts the growth of the new sector. Firstly, due to the low salinity the number of potentially cultivated species is low and the spatially explicit production potential of these macroalgae is poorly known. However, work is being done to understand the production potential of key macroalgal species in the BSR [24]. Secondly, widely used cultivation techniques are not appropriate for cultivation of macroalgae native in a significant part of the Baltic Sea. For example, S. latissima is the only macroalgal species that has currently viable farming solutions in the Baltic Sea [25], but the farming of S. latissima is only economically feasible in the westernmost Baltic Sea [13]. Moreover, new farmers face intermittent political will at different levels of governance, from the EU to state and local authorities, and need to navigate unclear rights of access to space and resources at a time of increasing sea use [2].

Maritime spatial planning (MSP) was introduced in the European Union (EU) as a multi-sectoral, multi-level spatial, place-based planning instrument to address issues of marine regulation fragmentation [26] and accommodate new sectors including offshore renewable energy production, aquaculture, and new types of tourism, which entails use-use as well as use-environment interaction analysis [27-29].

Assessment of interactions among maritime sectors and their potential for co-location is an essential aspect of MSP as marine space becomes increasingly crowded [29]. Crosssectoral considerations and negotiations of claims for space is important for the development of the marine macroalgae cultivation sector, as it tends to take place in the particularly busy coastal waters due to environmental, technical, and economic reasons [2,3]. Co- 
location of activities-their occurrence at the same time and space, where one user's resource needs may be positively or negatively impacted by other uses [29], which can in some cases give rise to sea space "multi-use" - is a synergetic or almost symbiotic interaction. At other times, activities may not complement each other and result in either exclusion of some activities from specific zones or more nuanced use-use interactions underpinned by a variety of spatial, temporal, provisional, and functional reasons $[29,30]$. Multi-purpose platforms, a combination of offshore wind farms and aquaculture systems, are an example of multi-use and a way of lowering the costs of development as well as optimising the use of marine space through shared infrastructure, yet are still largely a concept [31].

In addition to the cross-sectoral scope of MSP, suitable site pre-selection, streamlined regulations, and licensing procedures through MSP could lower the levels of uncertainty, speed up the decision-making process, and increase investor interest in currently nonexisting maritime sectors [32]. The significance of being included in spatial planning for a new sector is illustrated by the success story of offshore wind farms in northern Europe, where use-use as well as use-environment suitability assessments and strategic mapping were carried out to support the development of the sector prior to the conception of specific projects [33]. Consideration of marine aquaculture as a prospective future use is expected at the EU level and can be observed in some national MSPs, but specific sites for development are rarely designated [32].

The aim of the study is to explore the level of support in a handful of current Baltic Sea MSPs for the development of a macroalgae cultivation sector and the degree to which these MSP processes consider co-location options for this sector. Thereby, the study wants to present highlights on key social challenges and enablers for this sector, as well as contribute to new analytical ways of incorporating co-location considerations into the concept of social sustainability, which is necessary due to increasingly crowded seas.

A comparative case study analysis of MSPs of three eastern Baltic Sea coastal countriesEstonia, Latvia, and Poland-was performed to answer the following key questions on social sustainability related to macroalgae cultivation:

(a) To what extent have macroalgae cultivation interests been recognised as well as socially and spatially represented in the existing MSPs in these countries?

(b) To what degree have interactions between macroalgae cultivation and other maritime sectors and opportunities for co-location been considered during the implementation of these MSPs?

The focus of this study is the analysis of the socially constructed environment for cross-sectoral sector development, with a particular focus on macroalgae and its useuse interactions (co-location options). Therefore, the questions of production suitability and use-environment interaction were out of scope, but are covered in other studies (e.g., [2,4]). Similarly, it was not the environmental conditions for co-location options that were investigated in this study, but the degree to which the eastern Baltic MSP processes consider such co-location potentials when planning for macroalgae cultivation.

\section{Materials and Methods}

\subsection{Study Sites}

A detailed description of the conceptual approach and methods employed follows the introduction to the case studies.

Estonia, Latvia, and Poland, as well as the marine waters under their jurisdiction (see Figure 1), were chosen as case study countries due to similar environmental conditions; relatively low salinity surface waters at around 5-8 psu (practical salinity unit) in Poland and the Latvian Open Baltic coast, and 2-7 psu in the Gulf of Riga and in the coastal waters and Estonian Archipelago [34-36], being one reason. 


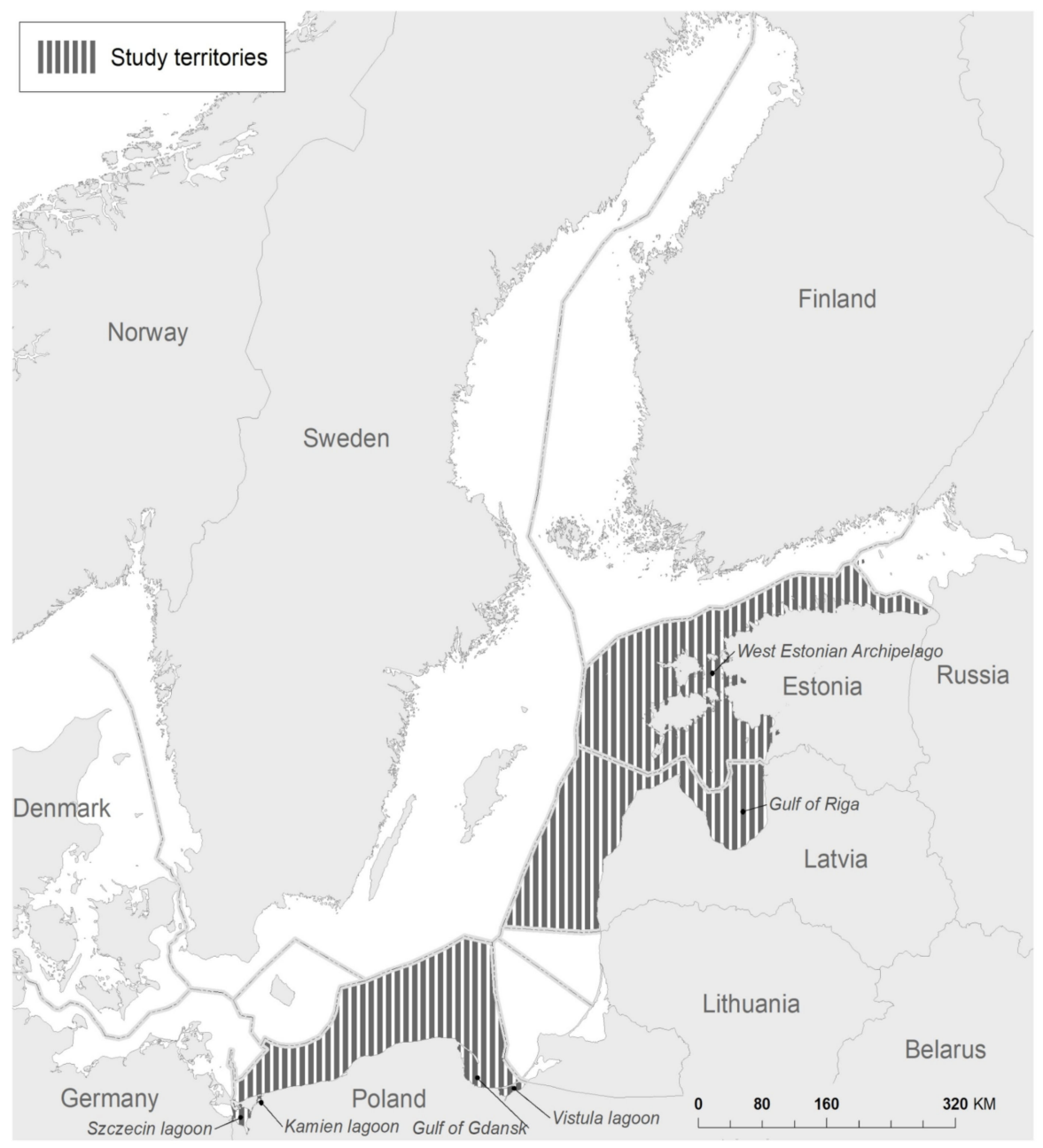

Figure 1. The case study country marine waters (exclusive economic zone and territorial waters) in the Baltic Sea.

Other reasons, also closely linked to the environmental conditions, were the shared types of native macroalgae species between these countries [37] and the similar history of their use. Records show that macroalgae, namely F. lumbricalis or F. vesiculosus, have been harvested at a commercial scale at various times along the Polish, Latvian, and Estonian coasts since the 1960s, to produce agar, iodine, alginic acid, and animal feed [13,38-40]. However, as of a result of a decline in the abundance of $F$. vesiculosus and F. lumbricalis due to combined impacts of overexploitation [41] and the rapidly increasing eutrophication in this coastal area [42], by 1973 commercial macroalgae harvesting started to be unprofitable in Poland [43] and by the 1990s agar production stopped in Latvia. At present, the West Estonian Archipelago (see Figure 1) is the only place in the Baltic Sea where F. lumbricalis is still present and harvested on a commercial scale. The red algae are either collected on the shore or the loose-lying form of the species is trawled from the seabed from the two locations within the archipelago. At sea, F. lumbricalis is legally owned by the state and its harvest is strictly regulated by the Estonian Fishing Act [44] to protect the species from overexploitation. Beach-cast wrack, organic material including macroalgae washed up ashore, was traditionally gathered by residents of coastal communities in parts of all case study countries and is still considered as part of the cultural heritage. Further, scientists in Poland have been exploring the possibilities of using beach wrack in biogas systems popular tourist municipalities $[45,46]$.

In addition to the above-mentioned reasons, the case studies have relatively welldocumented and comparable MSP processes centred on the EU MSP Directive [27] (Table A1. 
This made it possible to focus on the national scale regulatory and social systems differences between the case studies.

\subsection{The Conceptual Approach, Data Gathering, and Analysis}

\subsubsection{Theoretical Background}

The MSP Directive describes the aim of maritime spatial planning as "promoting the sustainable growth of maritime economies, the sustainable development of marine areas and the sustainable use of marine resources" [27] (Article 1). Thereby, it attempts to find area-based solutions for sustainable growth. In addition, it requires MSP to "take into account environmental, economic and social aspects, as well as safety aspects" [27] (Article 6) and "take into consideration relevant interactions of activities and uses" [27] (Article 8). Sustainability and cross-sectoral management are, thus, key concepts for MSP in Europe. Sometimes, MSP is highlighted to be an integrative process with the potential for increased fairness through systematic trade-offs and cross-sectoral considerations [47]. However, elsewhere in the literature has put to the attention the power imbalances at stake in MSP processes [48].

Participation and stakeholder inclusion is also at the core of MSP [27] (Article 9) and various parts of the literature have focused on capacity building and methods for participation (e.g., [49-51]. For example, Morf et al. [49] highlights how stakeholder inclusion can be categorised on a participation ladder from information to deep decision involvement of stakeholders, who could be, e.g., national planners, local planners, NGOs, and citizens. However, social sustainability has until recently received little attention in MSP [52]. An analytical framework for evaluating social sustainability and justice in MSP is developed by Saunders et al. [53]. The framework includes the concepts of recognition as the perceived legitimacy of the actors and their stakes in MSP by the planning authorities, representation as the determinants of meaningful participation and inclusion in the decisionmaking process, and distribution of goods and bads as the fairness of the distribution of resources and burdens in society as a result of decision-making [53].

Due to the lack of historical claims to an area, it can be harder for a new sector to be recognised politically and legally as well as be represented socially in the MSP process. This is especially the case if other, more traditional uses claim the same marine spaces, which could create a power imbalance [54]. Such a power imbalance can be increased, if the new sector is not spatially represented in maps. This is because, to be visible for decision-makers and to "be heard in decision-making" in MSP, each use needs to have its claims for marine space made spatially visible [55]. When claims are made spatially visible, trade-offs and negotiations regarding spatial distribution can take place [56].

While trade-offs and conflict management have been at the centre of attention in marine management for multiple decades, the pressure on marine space continues to grow [57]. With increasingly crowded seas, it becomes more important to recognise and represent different sectors while also managing their often-overlapping claims for space [56]. The concepts of co-location and multi-use have gained attention within recent years, as ways to foster synergies between spatial claims from different sectors to better optimize the use of marine space, as it is becoming scarcer [58]. Co-location describes the ambition of enabling synergic marine uses to share or contribute to the resources of each other, when possible, e.g., through multi-use constellations where uses actively share resources [29].

Bringing this together, it is important for MSP to recognise uses, especially a new marine use such as macroalgae cultivation. Furthermore, it is important for MSP to ensure that such a new use is represented on maps to be included in MSP. Additionally, MSP needs to investigate options for co-locating such a new use with other marine uses to ensure space for it in increasingly crowded seas. 


\subsubsection{Qualitative Content Analysis and Observer Knowledge: Sector Inclusion in MSP}

Inductive, qualitative content analysis is a systematic, close reading of text to identify key themes and patterns. During the analysis, the text is sorted or "coded" into a number of relevant themes, which arise during the process and are used as empirical data to compare the findings across different literature sources [59]. The key findings presented in this study are the result of a collaborative inductive, qualitative content analysis, searching for the degree to which macroalgae cultivation is recognised and represented in existing MSP. The analysis was carried out in the summer of 2021 and was concentrated on the MSPs publicly available at the time, accompanying documents, communications, and outputs of international projects focused on MSP gathered through the national planning authorities (see Table 1).

Table 1. Planning documents analysed (Full reference available in the list of references).

\begin{tabular}{|c|c|c|}
\hline Country & Planning Document Description/Title & Date of Publication \\
\hline \multirow{7}{*}{ Estonia } & Estonian Maritime Spatial Plan [60] & 2020 \\
\hline & $\begin{array}{l}\text { Hiiu maakonna merealade planeering (Hiiu County Maritime Spatial } \\
\text { Plan) [61] }\end{array}$ & 2018 \\
\hline & $\begin{array}{l}\text { Pärnu maakonnaga piirneva mereala maakonnaplaneering (County } \\
\text { plan of the maritime area bordering Pärnu County) [62] }\end{array}$ & 2017 \\
\hline & $\begin{array}{l}\text { Põllumajanduse ja kalanduse valdkonna arengukava aastani } 2030 \\
\text { (Development plan for agriculture and fisheries until 2030) [63] }\end{array}$ & 2021 \\
\hline & $\begin{array}{l}\text { Summary table of proposals submitted to the Estonian Maritime } \\
\text { Spatial Plan and the positions of the Ministry of Finance [64] }\end{array}$ & 2021 \\
\hline & Consultations table for Estonian MSP [65] & 2021 \\
\hline & Protocols of public consultation meetings (2019-2020) [66] & 2019-2020 \\
\hline \multirow{5}{*}{ Latvia } & $\begin{array}{l}\text { Ministry of Agriculture of the Republic of Latvia. Multiannual } \\
\text { Framework for Aquaculture Development 2014-2020 [67] }\end{array}$ & 2013 \\
\hline & $\begin{array}{l}\text { Maritime Spatial Plan 2030, The Maritime Spatial Plan for the Marine } \\
\text { Inland Waters, Territorial Sea and Exclusive Economic Zone Waters of } \\
\text { the Republic of Latvia [68] }\end{array}$ & 2019 \\
\hline & $\begin{array}{l}\text { Ministry of Agriculture of the Republic of Latvia. Operational } \\
\text { Programme for fisheries development [69] }\end{array}$ & 2021 \\
\hline & Maritime Spatial Plan 2030 Environmental report [70] & 2019 \\
\hline & Summary of public consultations [71] & 2018 \\
\hline \multirow{10}{*}{ Poland } & $\begin{array}{l}\text { Maritime Spatial Plan for the Internal Marine Waters, Territorial } \\
\text { Waters and Exclusive Economic Zone of the Republic of Latvia, 1st } \\
\text { draft [72] }\end{array}$ & 2016 \\
\hline & $\begin{array}{l}\text { Developing a Pilot Maritime Spatial Plan for the Western Coast of } \\
\text { Latvia (BaltSeaPlan Report 16) [73] }\end{array}$ & 2011 \\
\hline & Plan zagospodarowania przestrzennego Polskich Obszarów & \\
\hline & Morskich w skali 1:200,000 (Spatial Development Plan of Polish & 2021 \\
\hline & Maritime Areas at scale 1:200,000) [74] & \\
\hline & Projekt planu zagospodarowania przestrzennego Szczecin and & \\
\hline & $\begin{array}{l}\text { Kamieński Lagoon (Draft Spatial Development Plan for the Szczecin } \\
\text { and Kamieński Lagoon) [75] }\end{array}$ & 2021 \\
\hline & $\begin{array}{l}\text { Projekt planu zagospodarowania przestrzennego Zalewu Wiślanego } \\
\text { (Draft Spatial Management Plan for the Vistula Lagoon) [76] } \\
\text { Szczegółowy projekt planu zagospodarowania przestrzennego }\end{array}$ & 2021 \\
\hline & $\begin{array}{l}\text { Zatoki Gdańskiej (Detailed design of the spatial development plan } \\
\text { for the Gulf of Gdansk) [77] }\end{array}$ & 2021 \\
\hline & Study of Conditions of Spatial Development of Polish Sea Areas [78] & 2016 \\
\hline
\end{tabular}

In the content analysis, an inclusive interpretation of the concepts of recognition and representation was applied. The third analytical category of the Saunders et al. [53] framework, distribution of goods and bads, was addressed through the analysis of spatial representation and opportunities for co-location, which indicated the degree of access to space (the lack of which would be considered an obstacle or a "burden" for the sector). 
First, in addition to overt recognition in laws, regulations, and policy, the acknowledgement of interest legitimacy through "informal" means such as invitations to private meetings and inclusion in capacity building projects $[53,79]$ were also considered as signs of recognition in this study. The insider knowledge by the authors of this article and their experiences as observers of and participants in national MSP processes, as well as from their experience in the GRASS project, provided triangulation and insight into the "informal" processes within MSP and were used to contextualise some of the findings of the content analysis in this study.

Second, the representation studied covers both social representation in the MSP process through executed participation (not just invitations) as well as spatial representation in the map.

\subsubsection{Classification of Co-Location Opportunities in MSP}

In all three case study countries, stakeholder consultations took place in preparation of the MSP. Based on information gathered during such stakeholder consultations, use-use interactions among sectors have been evaluated roughly in each country already $[60,78,80,81]$.

In this study, the descriptions of the interactions between macroalgae cultivation activities and all other considered maritime sectors in the official MSPs were given more details based on the investigated MSP material. More specifically, the use-use interaction classification was expanded with more details, by dividing the information out based on three categories: "conflicting", "synergetic", or "with potential for co-location under certain conditions". The three categories were further classified under the following four types of underlying "spatial-temporal links" [29] to indicate "drivers" and "barriers" for co-location and multi-use in a particular context [82]:

- Environmental links-uses affect the environment and resource needs of another use.

- Location links-marine activities take place at the water surface, within the water column and on the seabed and at different times, and can at times overlap, which can result in sharing or competition over marine space.

- User attraction links-change in the number of users due to the proximity of activities.

- Technical links_concerning infrastructure, tools, or safety.

These links were used to develop a colour-coded use-use interaction matrix that was used to describe current considerations and opportunities for sector co-location in MSPs across the case study countries, from the macroalgae cultivation perspective.

Geodata depicting current and designated future sectoral uses featured in the use-use analysis were gathered through contact with the institutions responsible for the development of maps in each case study country and the HELCOM Map and Data Service [83]. The layers were grouped into categories, "conflicting", "synergetic", or "with potential for co-location under certain conditions", and colour-coded according to the findings of the use-use analysis previously described.

\section{Results}

3.1. Macroalgae Sector Inclusion in the MSP Processes

3.1.1. Recognition

A Formally Recognised "Future Use"

Macroalgae cultivation is a formally recognised part of the aquaculture and fisheries sector in all reviewed plans. Aquaculture of all types is listed in the Polish legal MSP procedure as an activity that had to be included in the planning processes by the planners and is the only sector that does not currently use the Polish marine space but was thoroughly investigated as a prospective use during the MSP process. In Poland, macroalgae cultivation is permitted to take place in areas "reserved for future use with extraction allowed", "environmentally conditioned local development", or "multifunctional economic growth", as well as basins designated for offshore wind energy and the exploration and extraction of natural resources. Similarly, in Latvia aquaculture is classified as a "general 
use", which will be evaluated on a case-by-case basis following the offshore installation licensing procedures, MSP recommendations on use-use interactions as well as the national, the thematic long-term development plan of the public coastal infrastructure, and local government interests if the offshore development is planned to take place within $2 \mathrm{~km}$ from the coastline.

\section{Environmental Benefits and Risks}

As they grow, macroalgae assimilate nutrients from the surrounding environment, which makes macroalgae cultivation and harvest an attractive activity from a Baltic Sea environmental management perspective as well as an instrument that could help to decrease the concentrations of phosphorus and nitrate over time [4]. This is described as one of the primary advantages of the activity in all reviewed plans and at times, in contrast to the negative impacts of fish farming [68] (p. 95).

However, the results of the Study of Conditions of Spatial Development of Polish Sea Areas conclude that cultivation may pose some threats to the environment. Further, the environmental impact assessment (EIA) for the draft plan for the Vistula Lagoon, Poland, does not recommend any type of aquaculture activities in the area unless it is experimental or "scientific research". Similarly, the current version of the draft plan for the Gulf of Gdansk excludes aquaculture, referring to the need to protect waters from pollution, and the final plan for the Szczecin and Kamień Lagoons allows aquaculture in seven basins, but the EIA is focused on the negative effects of fish aquaculture as well as the predicted negative effects of shellfish farming, recommending that all projects go through the Natura 2000 impact assessment process. Similarly, the Latvian plan states: "A significant negative impact [of macroalgae and shellfish farming] would be expected on fish spawning grounds and nurseries. Considering the potential environmental impact, aquaculture farms are not recommended in coastal waters up to $20 \mathrm{~m}$ depth".

\section{Limited Socio-Economic Significance}

In the Estonian Development Plan for Agriculture and Fisheries until 2030 [63], the Estonian MSP aquaculture is recognised as a regional development measure to attract investment outside metropolitan areas and "alleviate the seasonal nature of sea-based employment" through the involvement of "fishermen and other marine users in the maintenance of aquaculture facilities" [60] (p. 22) as well as an activity with potential to add value to coastal tourism and cultural heritage.

Apart from the recognition of the potential economic advantages of macroalgae farming as part of a multi-trophic aquaculture system, little attention is paid to the other socio-economic dimensions of the sector development and its significance in the Polish and Latvian plans. In the Latvian plan, wild grown algae are associated with the supply of some provisioning ecosystem services-raw resources for use in the production of other materials. However, there is no link between the service supply description and macroalgae cultivation activities.

\subsubsection{Representation}

Varying Degrees of Actor Representation

During the MSP consultation process in Poland, only 15 comments regarding aquaculture were submitted. Pressed by the legal obligation to consider the prospects of the aquaculture sector in MSP and a lack of interest during the public consultation process, the representation of the sector in Poland was limited to discussions between planners and experts.

In Latvia, the sector interests were represented at the national scale by the Ministry of Agriculture responsible for the aquaculture development strategy in Latvia, the national Multiannual Framework for Aquaculture Development 2014-2020 [67], which mentioned the option of marine aquaculture but did not formulate any goals towards this part of the sector and foresaw no targeted activities for development. The lack of focused actions 
was explained by the lack of MSP at that time. However, the operational plan for fisheries development 2021-2027 also indicates the need for investments only at freshwater aquaculture and, consequently, plans supporting activities only for this part of the sector [69], suggesting an overall "low" top level government interest in the development of macroalgae cultivation activities.

During the second draft consultation period in 2018, the Kurzeme planning region (coastal, westernmost part of Latvia) also provided feedback on the description of the sector, notably suggesting reviewing the plan's position discouraging co-location of aquaculture and other offshore installations such as oil platforms or wind farms, which was taken into account and the co-location of aquaculture and wind farms became permitted under certain conditions. Additionally, the authors are aware of a single rejected project proposal for commercial algae cultivation in the Gulf of Riga raised during the development of the second draft, suggesting there has been interest from the private sector; however, no records of private sector representatives participating in the consultation could be found.

Albeit very few in total, all the entrepreneurs currently involved in commercial macroalgae harvest in Estonia participated in the planning process. Due to the size of the private sector, it has close links and direct communication channels with the planning authority and research institutions monitoring wild stocks. Three thematic meetings were organized by the planning authority with aquaculture developers to introduce the MSP solutions to them and get their feedback for further development.

\section{Spatial Macroalgae Cultivation Representation during the Planning Process}

Aquaculture was included in the Study of Conditions of Spatial Development of Polish Sea Areas [78], based on the published literature and multidisciplinary expert and practitioner knowledge, which provided spatially explicit evidence for the decision-making process and use-use interaction analysis. Similarly, the natural growth potential of algae in the Estonian marine waters was modelled to produce maps depicting areas of high, moderate, and low production and to identify the most suitable sites for cultivation [60] (p. 24). Although these assessments resulted in the sector being "allowed" in areas where experts believe aquaculture will not conflict with other sectors in Poland, plus an environmental suitability map for macroalgae cultivation featured within the Estonian MSP, the sector was not designated space in the final MSPs.

In Latvia, the sector was temporarily included in the sectoral plan in the first draft of the Latvian MSP in 2016. In the plan, macroalgae cultivation was given the right to take place in "areas of potential development" along with other types of aquaculture, offshore renewable energy production, and maritime tourism, "taking into account limiting natural conditions, possible impact to marine ecosystem, as well as potential conflicts with other sea uses." [72] (p. 35). A total of $86.2 \mathrm{~km}^{2}$ of the coastal zone in the open Baltic were designated for algae and mussel cultivation activities [72,84,85], if they did not "create a threat to the marine ecosystem, shipping and national security", sectors of "primary interest" [72] (p.25), and fulfilled the conditions required by the regulations for development of offshore installations [86]. However, by 2019 the categories of uses of marine space were reviewed and the aquaculture sector is no longer spatially represented in the final plan.

\subsubsection{Technical Challenges and Knowledge Gaps as Barriers for Sector Recognition and Representation}

Knowledge gaps, absence of experience, and success stories from pilot studies, as well as anticipated conflicts with other users, are the key challenges in identifying the needs of the sector in all three case studies. For instance, the final Latvian MSP describes the development of the sector in the Latvian marine waters as limited by the environmental conditions said to be challenging for algae cultivation and a lack of technological solutions to resolve the challenges, and also calls for natural scientific institution and public body cooperation to fill in the knowledge gaps and advance the sector.

At the same time, discussions with planners suggests that expert knowledge and data providing a better understanding of the cultivation of zebra mussel in the Szczecin Lagoon 
have made an impact on their attitudes and made them less sceptical to marine farming, including macroalgae.

\subsection{Potential for Sector Co-Location}

The investigation of country-specific MSP documents on the stated nature of the interaction between macroalgae cultivation and other activities resulted in the following points.

For Estonia, "synergistic combined use of maritime space" is a goal within the action plan accompanying the Estonian MSP and multi-use, or "cluster solutions" through a common use of infrastructure and land-sea interaction, such as joint maintenance vessel use for the upkeep of infrastructure and species harvest, are encouraged in the Estonian MSP.

Multi-trophic aquaculture installations at sea-a combination of nutrient-adding fish farms with the nutrient-removing algae and shellfish farming-are promoted in the studied MSPs as an opportunity for multi-use motivated by all four types of links across the different countries (see Figure 2). The key drivers of the synergetic interaction include good technical links due to co-development of infrastructure and environmental benefits of such IMTA solutions [63,68]. In addition to this, in Estonia the possibility of increased user-attraction based on the economic benefits of added-value marine tourism, as a result of aquaculture practice, and high added-value aquaculture products, with high export potential (e.g., F. lumbricalis - protein pigments, nanocellulose), is suggested [63]. In Latvia, multi-trophic aquaculture is seen to have a role to play in reaching a long-term vision of sustainable fisheries helping "to improve the quality of the marine environment" [68] (p. 82).

The possibility of co-location between aquaculture and offshore wind farming is also discussed in all MSPs. In Estonia, shellfish and/or algae cultivation in wind energy development areas is proposed to achieve a positive synergy through combined use of space and infrastructure. In Latvia and Poland, co-location between the two sectors is also seen as potentially synergetic, but the offshore wind energy sector is considered a more strategically important future sector than aquaculture, classified as a "priority" sector and a "main function" determining the use of designated planning basins respectively. According to Latvian and Polish MSPs, co-location of the two sectors depends on the interest in technological development by offshore wind farm developers.

In Poland, as a general rule, wind farm structures should be built first (and only then should aquaculture structures be installed, with the permission of the Maritime Office). However, aquaculture is strictly prohibited in areas designated for existing activities of national strategic importance, including shipping and national defence, due to spatial overlap and concern of environmental impacts in marine protected areas. For instance, detailed plans for the Szczecin and Kamien Lagoons specify that aquaculture may be carried out at a distance of not less than $500 \mathrm{~m}$ from permanent fishing sites, military training areas, and fish spawning areas.

All these country-based points on macroalgae cultivation as well as other existing and future uses are summed up in the colour-coded interaction matrix presented in Figure 2. The matrix visually shows a cross-country comparison and has enabled the development of maps as presented in the following section. 


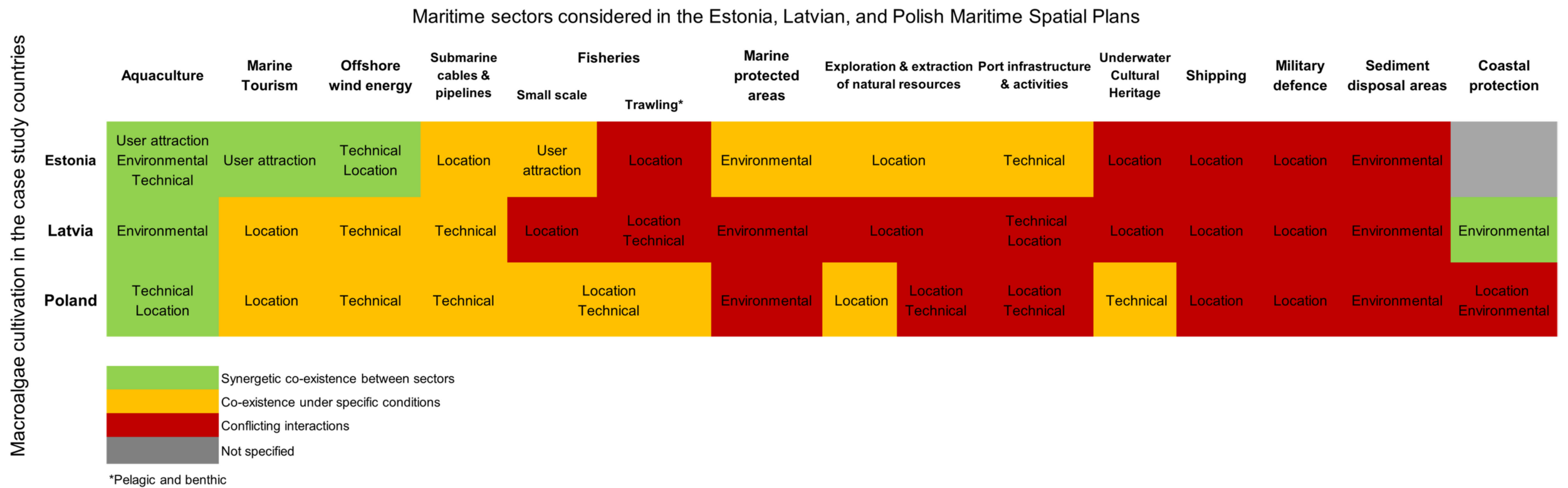

Figure 2. Categorisation of pairwise interactions between macroalgae cultivation and other maritime sectors, based on how the interactions appear in the official MSPs. 


\subsection{Spatial Representation of Use-Use Interactions and Potential for Co-Location}

Despite not being designated space, mapping of the pairwise interactions with macroalgae cultivation revealed that there are areas potentially available for the development of the sector in co-existence with other sectors in all studied countries as presented in Figures 3-5.

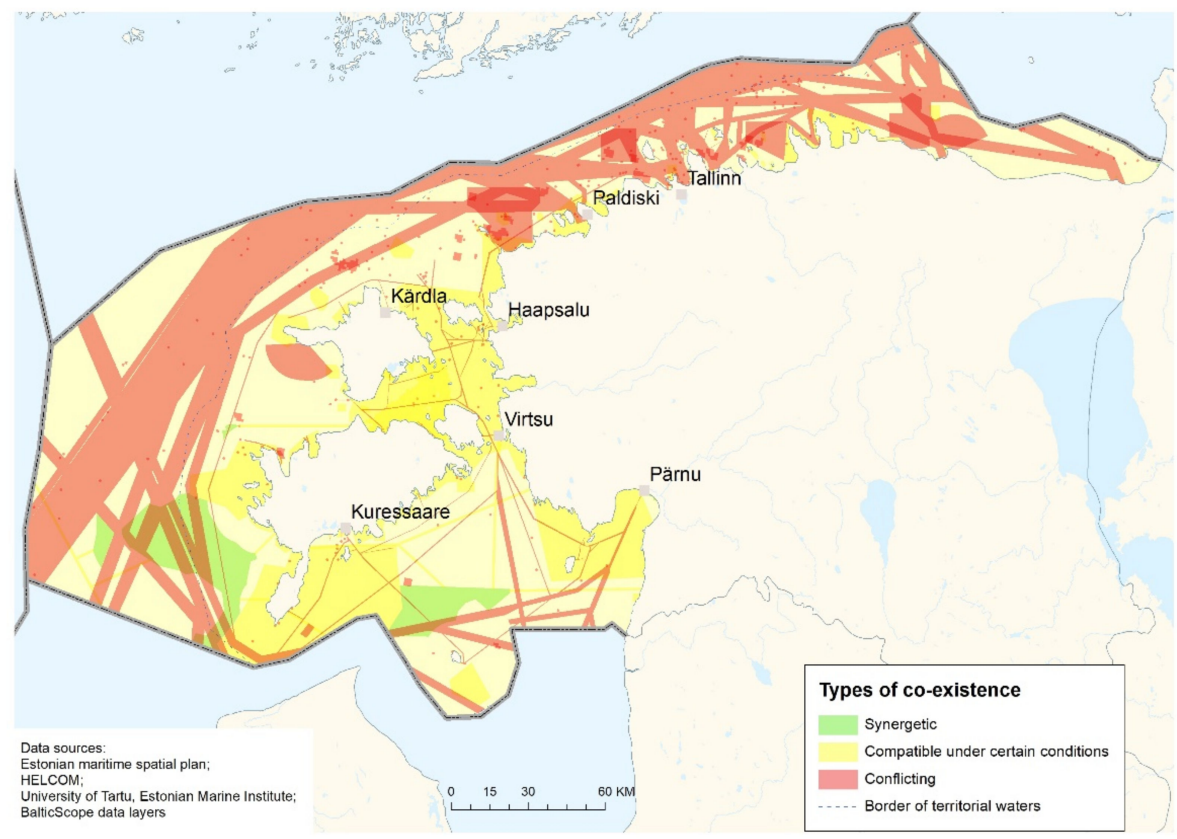

Figure 3. The Estonian marine space is divided into potentially synergetic, conflicting, and compatible sea use areas from a macroalgae cultivation perspective based, on sectoral maps featured in the current MSP considering existing and future sea uses.

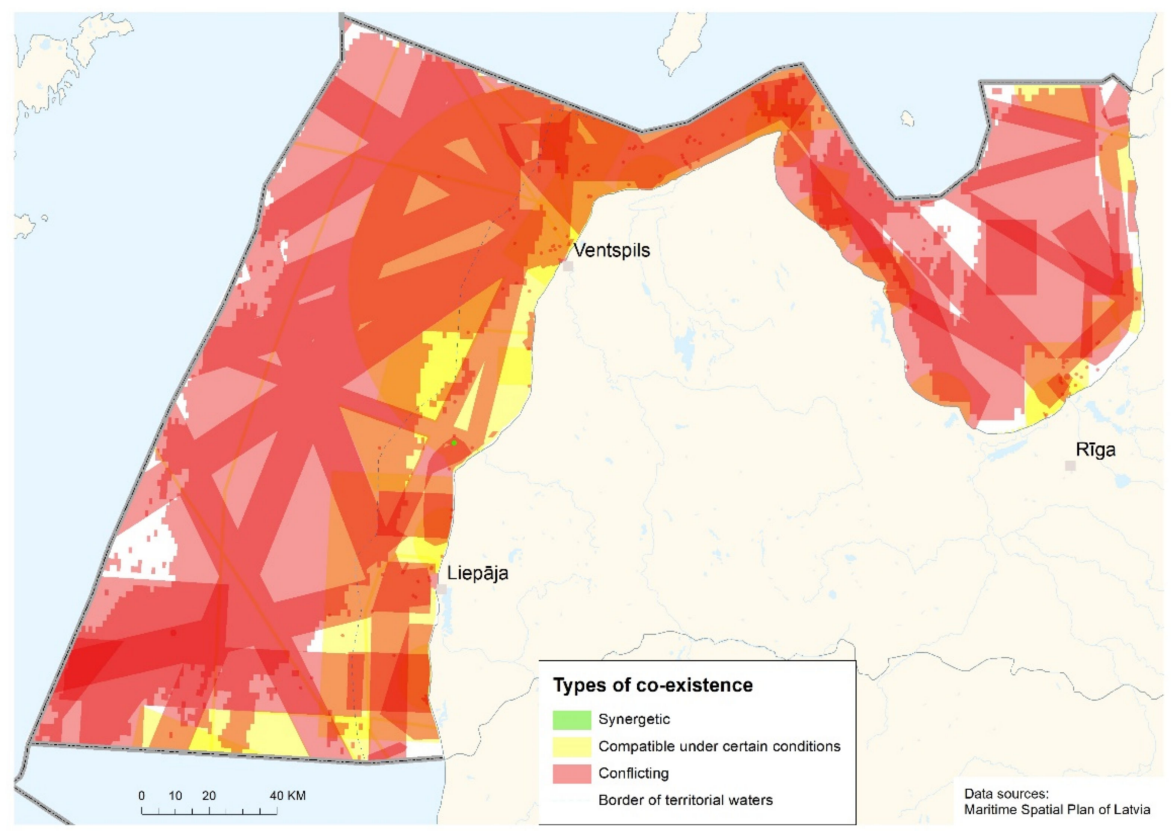

Figure 4. The Latvian marine space is divided into potentially synergetic, conflicting, and compatible sea use areas from a macroalgae cultivation perspective, based on sectoral maps featured in the current MSP considering existing and future sea uses. The single green dot symbolising synergetic coexistance with other aquaculture activties is the location of a mussel farm permitted and functioning as a site of scientific research. 


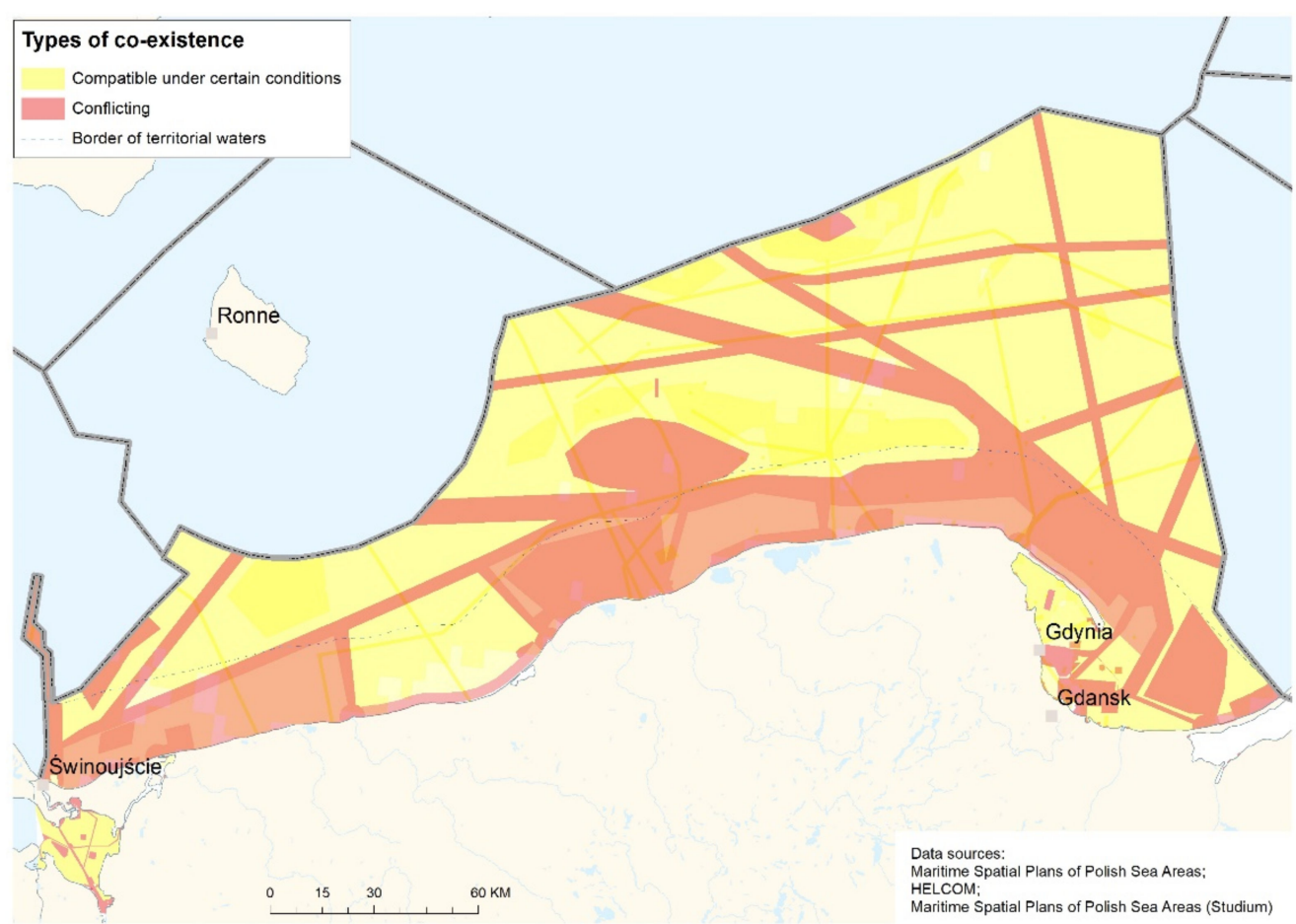

Figure 5. The Polish marine space is divided into potentially synergetic, conflicting, and compatible sea use areas from a macroalgae cultivation perspective, based on sectoral maps featured in the current MSP considering existing and future sea uses.

In Estonia, there are clear synergetic use areas, which are sites reserved for the future development of the offshore wind energy sector (Figure 3) [60].

In Latvia, most of the marine space seems to be already occupied by sectors, which conflict with macroalgae cultivation (Figure 4). This includes sectors such as shipping-well defined shipping routes are unmistakably visible, as well as military defence and fisheriesa mobile, temporally flexible activity present in most of the marine space (Figure 4). However, pockets of areas with potential for co-location can be seen along the open Baltic coast and the Gulf of Riga, which may also be the more environmentally suitable locations for cultivation of macroalgae [87].

In the Polish case, the map suggests that co-location may be possible near the coast and in the exclusive economic zone (EEZ). However, it is important to keep in mind that more detailed plans for the lagoons and the Gulf of Gdansk (Figure 1) (currently presented as areas with uses "Compatible under conditions") are being developed, thus the potential for co-location under certain conditions in the territorial zone may change in the near future.

\section{Discussion}

The increasing use of the seas and the rise of conflicts among and between existing and emerging maritime activities has led to the idea of co-locating activities in an effort to save space. Uses that can potentially be co-located with aquaculture include tourism, wind farms, and other offshore renewable energy structures; or oil and gas infrastructure $[88,89]$ and different aquaculture species may be farmed in conjunction as integrated multi-trophic aquaculture [90]. The potential for co-location depends on the spatial compatibility of the uses and the environmental suitability of the area for the respective activities [29,91]. However, to realize the co-location potential requires not only technological readiness, but also societal interest, societal and political willingness, and an adequate regulatory framework $[89,92,93]$. 
In the case study countries, co-location of aquaculture is promoted to varying degrees and with different sectors. While the countries were selected inter alia because of similar environmental conditions, it is clear that the environmental suitability for some aquaculture species, such as bivalves and certain types of macroalgae, decreases towards the east and north due to the decreasing salinity gradient. Therefore, it may be somewhat surprising that Estonia seemingly promotes the aquaculture sector the most and identifies more synergetic co-existence options for aquaculture (with tourism and offshore wind) than the other two case study countries. A potential explanation is the recognition of the social, economic, and environmental benefits of the (re)emerging aquaculture sector as well as the representation of the private sector actor interests in the Estonian MSP process, plus the close links between entrepreneurs, experts, and planning authorities as well as efforts to map, e.g., the potential of macroalgae growth. Such recognition may foster societal readiness and political willingness for the sector itself and its co-location possibilities.

In Latvia, the spatial representation of the aquaculture sector was not transferred into the final MSP plans, and a further study of the legal status of aquaculture in Latvia revealed a misalignment in the legislation and MSP, as the current regulations in force [94] identify eight additional permit areas for the installation and operation of equipment necessary for aquaculture activities, which are not referred to within the MSP. To operate at one of these sites, a project proposal must be reviewed by the Ministry of Agriculture regarding the planned activity through tender. In addition, the spatial co-location potential is the least, when compared to Estonia and Poland, which is likely due to the lack of political support and interest at the national level as well as a lack of private sector voices resulting in a onedimensional, environment-focused description of the benefits of macroalgae cultivation. Like in the other countries, the key obstacles preventing site designation were said to be technological and environmental uncertainty.

Whilst limited sector recognition and representation in MSP is an outcome of a number of different factors, including a shortage of actors with interests and experience, the end result is a "chicken and egg" situation or a "wicked" problem, where the spatial needs of a future sector are underrepresented in the plan due to a lack of actors and voices, which leads to weak support for sector development, lengthy offshore project permitting process, and, ultimately, a lack of investor interest [22,95]. Moreover, the case studies highlight that, as a regulatory system, MSP is a highly political process, which ends up creating an environment advantageous for some economic activities but not others [96] and, instead of levelling the playing field for all sectors, perpetuating the status quo and existing power differences [26].

In both Latvia and Poland, co-location of aquaculture with other sectors is only regarded feasible and permitted under specific conditions, e.g., as long as it does not interfere with the main uses of the sea. Poland, furthermore, foresees those installations, such as windfarms and extraction platforms, as needing to be built first and aquaculture developments should follow. However, it can be debated whether this is a feasible order of events. In a study from the UK, it is recommended to develop aquaculture projects and renewable energy infrastructure, such as wind farms, in conjunction, so that the legal rights in tenure are clear and secure and to ensure commercial viability [89]. Such codevelopment of offshore wind and aquaculture may also be better suited to highlight the less visible benefits of co-location for wind farm operators. To have synergetic co-existence between these two sectors, the benefits for both sides must be clear [89]. For the wind farm operators, the benefits may include offsetting of environmental impacts and a societal licence to operate $[89,93]$. However, it may also be necessary to create specific incentives for the larger sectors, such as offshore wind, to engage in co-location activities [97].

The co-location of offshore wind and aquaculture has been researched and suggested as a viable option for two decades [98], and the benefits are clear for the aquaculture sector [89]. However, in an MSP process not only the view of sectors that should be colocated count but also the other marine uses and stakeholders. In this study, the focus was on the inclusion of the aquaculture sector in the MSP process and the co-location 
potential; it was not investigated to what extent other sectors may have played a role in supporting or hindering the spatial recognition and representation of this sector. The Germany MSP process, just having finished the second planning cycle in the EEZ, provides an interesting example in this respect, as all the statements issued by different stakeholders and sector representatives are freely available online. Aquaculture is not a big actor in the German EEZ; it is not represented on the MSP maps and in the plan document, only the potential for co-location with wind farms and other installations is recognized. However, the official statements issued show that wind farm operators and the nature protection agency are largely against a co-location with aquaculture because of operational security concerns by the former and environmental concerns by the latter. Thus, even if co-location of aquaculture and wind farms is promoted politically, implementation may be aggravated by opposition from other sectors, not the least from the sector supposed to act as the "partner" in co-location.

There is not an easy solution to overcome the variety of problems for the aquaculture sector to become established. However, a needed step is the recognition and spatial representation of the sector in the MSP process, to literally put the sector on the map. Maps of co-location potential, as presented in this study, may furthermore support a clearer delineation of the spatial needs of the sector, visualize the "saved space" when utilizing the co-location potential, and shed light on the overall availability of space for macroalgae cultivation activities through opportunities for co-location and multi-use in each country; they have also been overlapped with maps depicting macroalgae production potential, to identify the most suitable locations for project development [87]. It is important to keep in mind that the mapping of sectors in three broad groups creates an impression that the interactions are well defined and "fixed" to a location; however, a different approach to mapping sector interactions (for instance, depicting the nature of the conflicts, synergies, and conditions of co-location), would reveal that interactions are much more nuanced.

Pilot sites for new marine uses and multi-use constellations are good enablers for new marine uses, and MSP can thus advantageously enable pilot facilities to take place [88]. Today, many MSPs operate as first versions. Therefore, these MSPs may become more detailed in time, as the plans are updated [99] and potentially consider European Commission initiatives like the comprehensive cross-sectoral EU Algae initiatives, currently in preparation. This might increase the number of marine uses that the plans cover, including macroalgae cultivation, and enable them to better facilitate multi-use.

At the same time, as an institutional management instrument MSP has been criticised for non-inclusive actor representation and providing limited opportunities for dialogue among sectors, making it ineffective at facilitating development of multi-use solutions [100]. Complementary social learning processes and alternative, less politically charged environments such as Communities of Practice, "groups of people who share a concern or a passion for something they do and learn how to do it better as they interact regularly" [100] (p. 2), may be necessary to initiate collaboration and, eventually, multi-use solutions [100].

\section{Conclusions}

This paper evaluated the degree to which the country-specific MSP implementations recognise and represent the macroalgae cultivation sector, and whether these MSPs consider use-use interactions for this sector, including its potential for synergic co-location with other marine activities.

The investigation showed that MSP does formally recognise parts of the aquaculture and fisheries sector in all reviewed plans, with macroalgae being mentioned as a potential future use. However, according to the MSPs and consultation protocols, the Estonian plan was the only plan where entrepreneurs participated in the planning process. The representation of the private sector was enabled by already established direct communication channels between the planners, experts, and the individuals from the sector. Furthermore, while the spatial representation was strong in all planning processes, these sectors are given little independent focus in the final MSPs. 
In all planning documents, co-location options between macroalgae-cultivation and other sectors are mentioned. While all countries in focus do mention multi-use potential that depends on technological development, the Latvian documents express the most concern for conflicts involving spatial overlaps with other sectors, which results in the least potential options in Latvia for locating macroalgae cultivation. However, in all three countries, conditionally compatible areas exist, underlining the need for considering colocation when planning for such new uses. The map for Estonian macroalgae cultivation potentials even shows synergic areas where windfarms are highlighted as a potential synergic combination option.

The sustainability development goals (SDGs) in the world are connected, and, thus, it is essential that MSP processes acknowledge such connectedness by, for example, considering how activities mutually interact. The analysis presented here supports the process of putting macroalgae cultivation on the map in reality, helping MSP facilitate options to locate this new sector. Co-location considerations are a necessity in this process, as the maps show, due to high competition for coastal marine space. Considering and spatially representing not only individual sectors, but also their interactions and multi-use potentials, as well as geospatial information on the environmental conditions for macroalgae cultivation, could ensure spatial locations with adequate social, political, and physical conditions as well as remove barriers for the development of the sector of macroalgal cultivation.

While the MSPs in Latvia, Poland, and Estonia already recognise the macroalgae cultivation sector to some extent, maps such as those presented in this study can facilitate further social recognition and representation, enabling the further inclusion of relevant stakeholders into the MSP processes, while supporting political and technical development of the sector. Future research is needed to investigate the development of this increasingly important new sector as the MSP plans are updated and pilot areas evolve.

Author Contributions: Conceptualization, A.A., I.B., I.A., I.M.B., A.I., J.K., L.L., A.K., I.P., S.S. (Solvita Strāke), S.S. (Sandra Sprukta), L.S. (Lena Szymanek), M.v.T., H.S.H., and L.S. (Lise Schrøder); methodology, A.A., I.B., I.M.B., and S.S. (Sandra Sprukta); formal analysis, A.A., I.B., A.I., J.K., L.L., A.K., I.P., S.S. (Solvita Strāke), and L.S. (Lena Szymanek); investigation, A.A., I.B., A.I., J.K., L.L., A.K., I.P., S.S. (Solvita Strāke), and L.S. (Lena Szymanek); writing—original draft preparation, A.A., I.M.B., J.K., L.L., A.K., I.P., L.S. (Lena Szymanek), M.v.T., H.S.H., and L.S. (Lise Schrøder); writing-review and editing, A.A., I.B., I.A., I.M.B., A.I., J.K., L.L., A.K., I.P., S.S. (Solvita Strāke)e, S.S. (Sandra Sprukta), L.S. (Lena Szymanek), M.v.T., H.S.H., and L.S. (Lise Schrøder); visualization, A.A., I.B., and S.S. (Sandra Sprukta); project administration, I.B. All authors have read and agreed to the published version of the manuscript.

Funding: This research was funded by the project GRASS (\#R097 Growing Algae Sustainably in the Baltic Sea), co-funded by the European Union's funding Programme Interreg Baltic Sea Region in 2014-2020 (European Regional Development Fund).

Institutional Review Board Statement: Not applicable.

Informed Consent Statement: Not applicable.

Data Availability Statement: The data presented in this study are available on request from the corresponding author.

Acknowledgments: This study has been supported by the project GRASS (\#R097 Growing Algae Sustainably in the Baltic Sea), co-funded by the European Union's funding Programme Interreg Baltic Sea Region in 2014-2020 (European Regional Development Fund). The authors wish to express grateful thanks to fellow GRASS project partners for their contribution and engaging discussions over the last few years.

Conflicts of Interest: The authors declare no conflict of interest. 


\section{Appendix A}

Table A1. Description of the MSP status and process in the case study countries.

A legally binding plan for the entire area was developed based on the Act on Sea Areas of Poland and Maritime Administration 2015 and has been in force since 21 May 2021. The Polish MSP provides the legal basis for decision-making and management of marine space and has a direct impact on the legal status and rights of sea users.

Legally binding, national scale plan for the entire marine area under the Estonian jurisdiction expected to be adopted in early 2022

Pilot plans for the Pärnu and Hiiu county

Status and scope the launch of the national scale plan and have now been integrated in the national plan.

National MSP based on the Planning Act 2015 and the pilot plans for Pärnu and Hiiu counties, on the earlier version of the Planning
A national scale plan for the entire marine waters under the national Latvian jurisdiction and the $2 \mathrm{~km}$ strip of internal waters mandated to coastal municipalities was adopted in May 2019. It is not legally binding.

The plan is based on the Spatial Development Planning Law (1 December 2011) and Regulation No. 740 of the Cabinet of Ministers on the Procedures for the Development Implementation and Monitoring of the Maritime spatial plan (30 October 2012).
Before the adoption of the EU MSP Directive, pilot plans were developed in 2008-2012 for: the western Gulf of Gdańsk, the Middle Bank, and the Bay of Pomerania. The pilot plans were non-binding but informed the Polish Maritime Administration decision-making process as a source of best available knowledge.

Separate, more detailed plans for the Szczecin Kamien, and Vistula lagoons as well as port areas are also being developed due to the high levels of existing or potential conflicts in the areas.

The final draft plan for the Szczecin and Kamień Lagoons was ready in 2019 but is still under consultation. The first out of three drafts for the Vistula Lagoon and the Gulf of Gdańsk have been prepared. Once approved, the gulf of Gdańsk plan (at a scale of 1: 25,000) will override the coarser MSP of the area. 
Table A1. Cont.

\section{Estonia}

Latvia

Poland

The plan will be the strategic basis for all decisions regulating sea use.

Its aim is to "attain and maintain a good status of the marine environment and to promote the maritime economy" while securing a "good environmental status, diverse and balanced

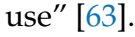

The two pilot plans were started on one hand, because of the wind farms, as more competing interests were emerging, whic were in conflict with each other and there was a need to find a balanced solution. The explanatory memorandum on the initiation of plans states that an important outcome of MSP is the avoidance or minimisation of conflicts between activities carried out and planned at sea, as well as between marine uses and nature. On the other hand, the aim was precisely to pilot the maritime planning process, as such plans have not been made in Estonia before. The experience of these two plans, although with a slightly different approach, has been used in the preparation of the national plan.

The key criteria for defining uses of the sea outlined in the first draft were:

"Rational use of the sea space and minimising

of the sea use conflicts", maintenance of the

"ecosystem integrity".

Further consideration of "possibilities of combined uses with similar demands for environmental conditions and infrastructure, not disturbing each other" and promotion of synergies between different uses:

Encouraging coexistence of the

complementary or interdependent (functionally related) sea uses." [72] (p. 33) 
Table A1. Cont.

The national marine plan at a scale of

1:200,000 divides the Polish marine space into 95 basins. In line with legislation, every basin has been assigned a "main function". Other activities-"allowed functions", may occur simultaneously within the basin as long as they do not disturb the main activity.

Activities not listed are not permitted within the basin. In addition, each basin must be

The plan focuses on the principles of spatial development, and the activities are not planned on a detailed scale. The plan provides guidelines and states conditions for the next stages of planning the activities, including at the local government level The planning solution was drafted on the basis of environmental considerations and the best available knowledge. The inclusion of the best available knowledge is ensured by a broad-based

Description of the planning approach
In the first draft of the MSP, the marine space and permitted uses are divided into four categories-"areas of priority interest" and uses of strategic importance; "areas of potential development" focused on new use with elements on uncertainty; "other types of uses of the sea and marine features" - all activities with pre-existing legal basis; and "areas of general use", which permit uses of any nature if they do not impact the environment and are legally permitted [72]. described in detail in terms of the existing conditions, the pressures occurring, the legal acts in force and the detailed principles of management and use of the resource, including the relationship between the different functions.

The planning process of the final MSP involved the preparation of a study of the conditions and four versions of the draft plan. All versions of the plan were subject to an ( (e.g, fishing, maritime transport), the rules of marine use predominantly been established; the plan focuses primarily on the combined use of the marine area and new uses of the sea. Guidelines are provided for all areas of activity to accommodate all different uses in the marine space [60] Environmental Impact Prediction as a part of strategic environmental impact assessment. A preliminary version of the "Study on the conditions of Spatial Development of Polish Maritime Areas with spatial analysis" was prepared in 2015, covering the exclusive economic zone, territorial sea and internal waters of the open coast [78]

This document describes the environmental aspects and aspects resulting from various forms of space use, also legal ones. It was the first source of knowledge to start the main MSP, first formal identification of actors and conflicts, but the solutions. 
Table A1. Cont.

\section{Estonia}

Authorities responsible

The Ministry of Finance

Public and sector consultation process November 2021)

\section{Latvia}

The Ministry of Environmental Protection and Regional Development (MoEPRD) with the support from other ministries and sector authorities responsible for the national MSP Local coastal municipality councils-coastal plan.

All interested parties were able to propose their suggestions on the values and uses of the maritime space during the planning phase. They were invited to map their ideas during the almost one-year period on the official MSP website.

http:/ / mereala.hendrikson.ee/ideekorje.html (accessed on 10

The planner has used a broad approach in stakeholder engagement using a variety of channels. All invitations for stakeholder meetings were published in national and regional newspapers; on Facebook; on the webpage of Ministry of

Finance and the dedicated planning webpage; e-mail invitation were sent to interested parties through mailing lists that included professional associations, participants from other similar meetings and people who had subscribed to the e-mails. Furthermore, physical posters were posted on frequented places such as notice boards in the town central squares. Content articles were published in several publications.

A round of thematic meetings with stakeholders was carried out during the preparation of the MSP, to validate the solution before they are made public and to discuss specific issues with relevan stakeholders.

MSP solutions were introduced at various international and national meetings, including introduction to aquaculture at the Baltic Blue Growth conference.
Detailed plan for public, sector and expert engagement [71]. "Priority sectors" such as shipping, and the offshore wind energy sector had targeted consultations with sectora representatives [65].

\section{Poland}

Polish Maritime Area is territorially divided

between Maritime Offices in Gdynia, Szczecin, and, until 2020, Słupsk. The Directors of

Maritime Offices are the local maritime administrative bodies of the Ministry responsible for maritime affairs and they are responsible for preparing and consulting the plans before implementation

There were four draft plans, each one was subject to public review.

In total, 2053 requests for change were submitted and the number of applicants was 232.

There were also eight sectoral $(\sim 8 * 50$ participants), four major national ( 700 participants), and three international consultation meetings ( $\sim 33^{*} 12$ participants). 
Table A1. Cont.

\section{Estonia}

Latvia

Poland

Existing and well-established uses have had a clear preference

when accommodating new uses. New uses need to be

Existing strategically important sectors

accommodated where the old ones do not exist. The wind

include shipping, fishing, tourism, national

energy sector has had the strongest influence out of the new uses security, and nature conservation.

Priority or strategically and much clearer objectives.

important sectors For example, an environmental NGO won

from the Hiiu MSP by ruling of the National Court of Estonia currently not existing.

Offshore wind farm development is also

foreseen in the near future, and the sector is 


\section{References}

1. Gentry, R.R.; Froehlich, H.E.; Grimm, D.; Kareiva, P.; Parke, M.; Rust, M.; Gaines, S.D.; Halpern, B.S. Mapping the global potential for marine aquaculture. Nat. Ecol. Evol. 2017, 1, 1317-1324. [CrossRef] [PubMed]

2. Araújo, R.; Vázquez Calderón, F.; Sánchez López, J.; Azevedo, I.C.; Bruhn, A.; Fluch, S.; Garcia Tasende, M.; Ghaderiardakani, F.; Ilmjärv, T.; Laurans, M.; et al. Current Status of the Algae Production Industry in Europe: An Emerging Sector of the Blue Bioeconomy. Front. Mar. Sci. 2021, 7, 1247. [CrossRef]

3. Gjertsen, A.; Bay-Larsen, I.; Bjørkhaug, H.; Vangelsten, B.V. Access to areas for algae cultivation in Norway. Mar. Policy 2020, 115, 103853. [CrossRef]

4. Campbell, I.; Macleod, A.; Sahlmann, C.; Neves, L.; Funderud, J.; Øverland, M.; Hughes, A.D.; Stanley, M. The environmental risks associated with the development of seaweed farming in Europe-Prioritising key knowledge gaps. Front. Mar. Sci. 2019, 6, 107. [CrossRef]

5. European Comission European Green Deal: Developing A Sustainable Blue Economy in the European Union. Available online: https: / / ec.europa.eu/commission/presscorner/detail/en/ip_21_2341 (accessed on 9 December 2021).

6. Hasselström, L.; Gröndahl, F. Payments for nutrient uptake in the blue bioeconomy-When to be careful and when to go for it. Mar. Pollut. Bull. 2021, 167, 112321. [CrossRef] [PubMed]

7. European Commission, Directorate-General for Health and Food Safety. Communication from the Commission to the European Parliament, the Council, the European Economic and Social Committee and the Committee of the Regions. A Farm to Fork Strategy for a Fair, Healthy and Environmentally-Friendly Food System; European Commission: Brussels, Belgium, 2020.

8. Duarte, C.M.; Wu, J.; Xiao, X.; Bruhn, A.; Krause-Jensen, D. Can seaweed farming play a role in climate change mitigation and adaptation? Front. Mar. Sci. 2017, 4, 100. [CrossRef]

9. Food and Agriculture Organization of the United Nations. The State of World Fisheries and Aquaculture 2020: Sustainability in Action; Food and Agriculture Organization of the United Nations: Rome, Italy, 2020.

10. HELCOM. State of the Baltic Sea-Second HELCOM Holistic Assessment 2011-2016. 2018. Available online: https://helcom.fi/ media/publications / BSEP155.pdf (accessed on 10 November 2021).

11. Reusch, T.B.H.; Dierking, J.; Andersson, H.C.; Bonsdorff, E.; Carstensen, J.; Casini, M.; Czajkowski, M.; Hasler, B.; Hinsby, K.; Hyytiäinen, K.; et al. The Baltic Sea as a time machine for the future coastal ocean. Sci. Adv. 2018, 4, eaar8195. [CrossRef]

12. Kersen, P.; Paalme, T.; Pajusalu, L.; Martin, G. Biotechnological applications of the red alga Furcellaria lumbricalis and its cultivation potential in the Baltic Sea. Bot. Mar. 2017, 60, 207-218. [CrossRef]

13. Weinberger, F.; Paalme, T.; Wikström, S.A. Seaweed resources of the Baltic Sea, Kattegat and German and Danish North Sea coasts. Bot. Mar. 2020, 63, 61-72. [CrossRef]

14. Skipper, L.; Calabuig, I.; Møller, J.; Wenøe Breddam, D.; Skovgaard Mathorne, J. Saccharina latissimi (Linnaeus) C.E.Lane, C.Mayes, Druehl \& G.W.Saunders, 2006. In National Checklist of All Species Occurring in Denmark; Miljøstyrelsen/The Danish Environmental Protection Agency: København, Denmark, 2020.

15. van Oirschot, R.; Thomas, J.E.; Gröndahl, F.; Fortuin, K.P.J.; Brandenburg, W.; Potting, J. Explorative environmental life cycle assessment for system design of seaweed cultivation and drying. Algal Res. 2017, 27, 43-54. [CrossRef]

16. Visch, W.; Kononets, M.; Hall, P.O.J.; Nylund, G.M.; Pavia, H. Environmental impact of kelp (Saccharina latissima) aquaculture. Mar. Pollut. Bull. 2020, 155, 110962. [CrossRef] [PubMed]

17. Brzeska-Roszczyk, P.; Barańska, A.; Kruk-Dowgiałło, L. Review of selected methods of macroalgae cultivation in the marine waters. BIM 2017, 32, 129-136. [CrossRef]

18. Suutari, M.; Leskinen, E.; Spilling, K.; Kostamo, K.; Seppälä, J. Nutrient removal by biomass accumulation on artificial substrata in the northern Baltic Sea. J. Appl. Phycol. 2016, 29, 1707-1720. [CrossRef]

19. Christiansen, E.R. The Potential of Ulva for Bioremediation and for Food and Feed. Master's Thesis, National Food Institute, Aarhus University, Kongens Lyngby, Denmark, 2018. Available online: https:/ / docplayer.dk/154782299-And-for-food-and-feed. html (accessed on 10 November 2021).

20. Anneliis Kõivupuu. Macroalgae Sector in Estonia: Past, Present and Future Perspectives. 2021. Available online: https://www. kurzemesregions.lv/wp-content/uploads/2021/05/Estonia-macroalgae-sector_Anneliis.pdf (accessed on 10 November 2021).

21. Meichssner, R.; Stegmann, N.; Cosin, A.; Sachs, D.; Bressan, M.; Marx, H.; Krost, P.; Schulz, R. Control of fouling in the aquaculture of Fucus vesiculosus and Fucus serratus by regular desiccation. J. Appl. Phycol. 2020, 32, 4145-4158. [CrossRef]

22. Lähteenmäki-Uutela, A.; Rahikainen, M.; Lonkila, A.; Yang, B. Alternative proteins and EU food law. Food Control 2021, 130, 108336. [CrossRef]

23. Thomas, J.E.; Ramos, F.S.; Gröndahl, F. Identifying Suitable Sites for Macroalgae Cultivation on the Swedish West Coast. Coast. Manag. 2019, 47, 88-106. [CrossRef]

24. Kotta, J.; Jänes, H.; Paalme, T.; Peterson, A.; Kotta, I.; Aps, R.; Szava-Kovats, R.; Kaasik, A.; Fetissov, M. GoA 2.1. Assessing the PanBaltic Potential of Macroalgae Cultivation and of Harvesting Wild Stocks. 2021. Available online: https:/ / www.submariner-network.eu/images /grass/outputs/GRASS_OA21_pan-Baltic_map_depicting_potential_of_ macroalgal_cultivation_and_harvesting.pdf (accessed on 10 November 2021). 
25. Peteiro, C.; Sánchez, N.; Martínez, B. Mariculture of the Asian kelp Undaria pinnatifida and the native kelp Saccharina latissima along the Atlantic coast of Southern Europe: An overview. Algal Res. 2016, 15, 9-23. [CrossRef]

26. Saunders, F.; Gilek, M.; Day, J.; Hassler, B.; McCann, J.; Smythe, T. Examining the role of integration in marine spatial planning: Towards an analytical framework to understand challenges in diverse settings. Ocean Coast. Manag. 2019, 169, 1-9. [CrossRef]

27. Directive 2014/89/EU of the European Parliament and of the Council of 23 July 2014. Establishing A Framework for Maritime Spatial Planning. 2014. Available online: http:/ / data.europa.eu/eli/dir/2014/89/oj (accessed on 10 November 2021).

28. Ntona, M.; Morgera, E. Connecting SDG 14 with the other Sustainable Development Goals through marine spatial planning. Mar. Policy 2018, 93, 214-222. [CrossRef]

29. Bonnevie, I.M.; Hansen, H.S.; Schrøder, L. Assessing use-use interactions at sea: A theoretical framework for spatial decision support tools facilitating co-location in maritime spatial planning. Mar. Policy 2019, 106, 103533. [CrossRef]

30. Schupp, M.F.; Bocci, M.; Depellegrin, D.; Kafas, A.; Kyriazi, Z.; Lukic, I.; Schultz-Zehden, A.; Krause, G.; Onyango, V.; Buck, B.H. Toward a Common Understanding of Ocean Multi-Use. Front. Mar. Sci. 2019, 6, 165. [CrossRef]

31. Abhinav, K.A.; Collu, M.; Benjamins, S.; Cai, H.; Hughes, A.; Jiang, B.; Jude, S.; Leithead, W.; Lin, C.; Liu, H.; et al. Offshore multi-purpose platforms for a Blue Growth: A technological, environmental and socio-economic review. Sci. Total Environ. 2020, 734, 138256. [CrossRef] [PubMed]

32. Stelzenmuüller, V.; Gimpel, A.; Gopnik, M.; Gee, K. Aquaculture Site-Selection and Marine Spatial Planning: The Roles of GIS-Based Tools and Models. In Aquaculture Perspective of Multi-Use Sites in the Open Ocean; Buck, B., Langan, R., Eds.; Springer International Publishing: New York, NY, USA, 2017.

33. Jay, S. Planners to the rescue: Spatial planning facilitating the development of offshore wind energy. Mar. Pollut. Bull. 2010, 60, 493-499. [CrossRef] [PubMed]

34. Kotta, J.; Paalme, T.; Kersen, P.; Martin, G.; Herkül, K.; Möller, T. Density dependent growth of the red algae Furcellaria lumbricalis and Coccotylus truncatus in the West Estonian Archipelago Sea, northern Baltic Sea. Oceanologia 2008, 50, 577-585.

35. Skudra, M.; Lips, U. Characteristics and inter-annual changes in temperature, salinity and density distribution in the Gulf of Riga. Oceanologia 2017, 59, 37-48. [CrossRef]

36. Świątek, M. Long-term variability of water temperature and salinity at the Polish coast. Bull. Geogr. Phys. Geogr. Ser. 2019, 16, 115-130. [CrossRef]

37. HELCOM. Checklist of Baltic Sea Macro-Species. Baltic Sea Environment Proceedings No. 13. 2012. Available online: https: //www.helcom.fi/wp-content/uploads/2019/08/BSEP130-1.pdf (accessed on 10 November 2021).

38. Czapke, K. Agar-agar z krajowego surowca (Agar-agar from national resource). Przem. Spoż. 1961, 15, 12-17.

39. Czapke, K. Widlik bałtycki i agar-agar (Baltic Furcellaria and agar-agar). Przem. Spoż. 1963, 17, $22-26$.

40. Martin, G.; Paalme, T.; Torn, K. Growth and Production Rates of Loose-Lying and Attached Forms of the Red Algae Furcellaria lumbricalis and Coccotylus truncatus in Kassari Bay, the West Estonian Archipelago Sea. Hydrobiologia 2006, 554, 107-115. [CrossRef]

41. Ciszewski, P.; Ciszewska, I.; Kruk-Dowgiałło, L.; Osowiecki, A.; Rybicka, D.; Wiktor, J.; Wolska-Pyś, M.; Żmudziński, L.; Trokowicz, D. Trends of long-term alterations of the Puck Bay ecosystem. Stud. Mater. Oceanologiczne 1992, 60, 33-84.

42. Pliński, M.; Florczyk, I. Changes in the phytobenthos resulting from the eutrophication of Puck Bay. Limnologica 1984, 15, 325-327.

43. Ślesińska, B. Skład gatunkowy roślin w połowach prowadzonych przy eksploatacji widlika w Zatoce Puckiej (The species composition of plants taken when collecting Furcellaria from Puck Bay). Zesz. Nauk. Wydz. Biol. Nauk Ziemi Uniw. Gdań. 1977, 3, 139-148.

44. Riigikogu. Estonian Fishing Act 2015. 2015. Available online: http:/ / extwprlegs1.fao.org/docs/pdf/est178448ENG.pdf (accessed on 10 November 2021).

45. Bucholc, K.; Szymczak-Żyła, M.; Lubecki, L.; Zamojska, A.; Hapter, P.; Tjernström, E.; Kowalewska, G. Nutrient content in macrophyta collected from southern Baltic Sea beaches in relation to eutrophication and biogas production. Sci. Total Environ. 2014, 473-474, 298-307. [CrossRef]

46. Filipkowska, A.; Lubecki, L.; Szymczak-Żyła, M.; Kowalewska, G.; Żbikowski, R.; Szefer, P. Utilisation of macroalgae from the Sopot beach (Baltic Sea). Oceanologia 2008, 50, 255-273.

47. Gee, K.; Blazauskas, N.; Dahl, K.; Göke, C.; Hassler, B.; Kannen, A.; Leposa, N.; Morf, A.; Strand, H.; Weig, B.; et al. Can tools contribute to integration in MSP? A comparative review of selected tools and approaches. Ocean Coast. Manag. 2019, $179,104834$. [CrossRef]

48. Flannery, W.; Ellis, G.; Ellis, G.; Flannery, W.; Nursey-Bray, M.; van Tatenhove, J.P.M.; Kelly, C.; Coffen-Smout, S.; Fairgrieve, R.; Knol, M.; et al. Exploring the winners and losers of marine environmental governance. Plann. Theory Pract. 2016, 17, 121-151. [CrossRef]

49. Morf, A.; Kull, M.; Piwowarczyk, J.; Gee, K. Chapter 10: Towards a Ladder of Marine/Maritime Spatial Planning Participation. In Maritime Spatial Planning, Past, Present, Future; Zaucha, J., Gee, K., Eds.; Palgrave Macmillan: Cham, Switzerland, 2019.

50. Twomey, S.; O’Mahony, C. Chapter 13: Stakeholder Processes in Marine Spatial Planning: Ambitions and Realities from the European Atlantic Experience. In Maritime Spatial Planning, Past, Present, Future; Zaucha, J., Gee, K., Eds.; Palgrave Macmillan: Cham, Switzerland, 2019.

51. Gopnik, M.; Fieseler, C.; Cantral, L.; McClellan, K.; Pendleton, L.; Crowder, L. Coming to the table: Early stakeholder engagement in marine spatial planning. Mar. Policy 2012, 36, 1139-1149. [CrossRef] 
52. Frederiksen, P.; Morf, A.; von Thenen, M.; Armoskaite, A.; Luhtala, H.; Schiele, K.S.; Strake, S.; Hansen, H.S. Proposing an ecosystem services-based framework to assess sustainability impacts of maritime spatial plans (MSP-SA). Ocean Coast. Manag. 2021, 208, 105577. [CrossRef]

53. Saunders, F.; Gilek, M.; Ikauniece, A.; Tafon, R.V.; Gee, K.; Zaucha, J. Theorizing Social Sustainability and Justice in Marine Spatial Planning: Democracy, Diversity, and Equity. Sustainability 2020, 12, 2560. [CrossRef]

54. Schultz-Zehden, A.; Lukic, I.; Onwona Ansong, J.; Altvater, S.; Bamlett, R.; Barbanti, A.; Bocci, M.; Buck, B.H.; Calado, H.; Caña Varona, M.; et al. Ocean Multi-Use Action Plan; MUSES Project; Multi-Use in European Seas: Edinburgh, UK, 2018.

55. Gee, K.; Kannen, A.; Adlam, R.; Brooks, C.; Chapman, M.; Cormier, R.; Fischer, C.; Fletcher, S.; Gubbins, M.; Shucksmith, R.; et al. Identifying culturally significant areas for marine spatial planning. Ocean Coast. Manag. 2017, 136, 139-147. [CrossRef]

56. Gimpel, A.; Stelzenmüller, V.; Töpsch, S.; Galparsoro, I.; Gubbins, M.; Miller, D.; Murillas, A.; Murray, A.G.; Pınarbaş1, K.; Roca, G.; et al. A GIS-based tool for an integrated assessment of spatial planning trade-offs with aquaculture. Sci. Total Environ. 2018, 627, 1644-1655. [CrossRef]

57. Kyriazi, Z. From identification of compatibilities and conflicts to reaching marine spatial allocation agreements. Review of actions required and relevant tools and processes. Ocean Coast. Manag. 2018, 166, 103-112. [CrossRef]

58. Przedrzymirska, J.; Zaucha, J.; Depellgrin, D.; Fairgrieve, R.; Kafas, A.; Calado, H.M.G.P.; de Sousa Vergílio, M.H.; Varona, M.C.; Lazić, M.; Schultz-Zehden, A.; et al. Multi-use of the sea: From research to practice. SHS Web Conf. 2018, 58, 01025. [CrossRef]

59. Hall, D.M.; Steiner, R. Insect pollinator conservation policy innovations at subnational levels: Lessons for lawmakers. Environ. Sci. Policy 2019, 93, 118-128. [CrossRef]

60. Rahandusministeerium. Maritime Spatial Plan; Rahandusministeerium Estonian: Tallinn, Estonia, 2020. (In Estonian)

61. Rahandusministeerium. Hiiu Maakonna Merealade Planeering; Rahandusministeerium Estonian: Tallinn, Estonia, 2018.

62. Rahandusministeerium. Pärnu Maakonnaga Piirneva Mereala Maakonnaplaneering; Rahandusministeerium Estonian: Tallinn, Estonia, 2017.

63. Republic of Estonian Ministry of Rural Affairs. Põllumajanduse Ja Kalanduse Valdkonna Arengukava Aastani 2030 (Development Plan for Agriculture and Fisheries Until 2030). 2021. Available online: https://www.agri.ee/sites/default/files/content/ arengukavad/poka-2030/poka-2030-taistekst.pdf (accessed on 10 November 2021).

64. Estonian Maritime Spatial Plan. Summary table of proposals submitted to the Estonian maritime spatial plan and the positions of the Ministry of Finance. 2021. Available online: http:/ / mereala.hendrikson.ee/dokumendid/Planeeringulahendus/2021-11_ Ettepanekute_koondtabel.pdf (accessed on 10 November 2021).

65. Estonian Maritime Spatial Plan. Consultations table for Estonian MSP. 2021. Available online: http://mereala.hendrikson.ee/ dokumendid/Planeeringulahendus/2021-11_koosk\%C3\%B5lastuste_koondtabel.pdf (accessed on 10 November 2021).

66. Rahandusministeerium. Protocols of Public Consultation Meetings (2019-2020). Available online: http:/ / mereala.hendrikson.ee/ arutelud.html (accessed on 10 November 2021).

67. Ministry of Agriculture of the Republic of Latvia. Multiannual Framework for Aquaculture Development 2014-2020. 2013. Available online: https:/ /www.zm.gov.lv/public/files/CMS_Static_Page_Doc/00/00/00/35/82/akvakultura_2014.pdf (accessed on 10 November 2021).

68. Ministry of Environmental Protection and Regional Development of the Republic of Latvia. MARITIME SPATIAL PLAN 2030. The Maritime Spatial Plan for the Marine Inland Waters, Territorial Sea and Exclusive Economic Zone Waters of the Republic of Latvia. National Level Long-Term Spatial Development Planning Document. 2019. Available online: https: / / drive.google.com/file/d/1mKigVjv6N03cjgPkwR5RSItcQezsn5zY/view?usp=sharing (accessed on 10 November 2021).

69. Ministry of Agriculture of the Republic of Latvia. Operational Programme for Fisheries Development. 2021. Available online: https://www.zm.gov.lv/public/ck/files/ZM/zivis/LV_EJZF_ZRP_21_27\%20_ROJ_09_2021.pdf (accessed on 10 November 2021).

70. Ministry of the Environmental Protection and Regional Development of the Republic of Latvia. Maritime Spatial Plan 2030 Environmental Report; Ministry of the Environmental Protection and Regional Development of the Republic of Latvia: Rīga, Latvia, 2019.

71. Ministry of the Environmental Protection and Regional Development of the Republic of Latvia. Kopsavilkums Par Sabiedrības Iebildumiem Un Priekšlikumiem Jūras Plānojuma 2030 Un Tā Vides Pārskata Projektu Publiskajā Apspriešanā. Priekšlikumi Izkārtoti Atbilstoši Jūras Plānojuma 2030 2. Redakcijas Doku-Menta Struktūrai, Sākot Ar Vispārīgiem Priekšlikumiem (Summary of Public Consultations; In Latvian). 2018. Available online: https:/ /drive.google.com/file/d/1fZQNqj8Zn13_WK2Do1C5gPo2 4suba2je/view? usp=sharing (accessed on 10 November 2021).

72. Ministry of the Environmental Protection and Regional Development of the Republic of Latvia. Maritime Spatial Plan for the Internal Marine Waters, Territorial Waters and Exclusive Economic Zone of the Republic of Latvia; Summary; Ministry of the Environmental Protection and Regional Development of the Republic of Latvia: Rīga, Latvia, 2016.

73. Ruskule, A.; Veidemane, K. Developing a Pilot MSP for the Western Coast of Latvia. Environ. Forum Latv. 2012. [CrossRef]

74. Urząd Morski w Gdyni. Plan Zagospodarowania Przestrzennego Polskich Obszarów Morskich w Skali 1:200000. 2021. Available online: https: / / www.umgdy.gov.pl/?cat=274 (accessed on 10 November 2021).

75. Urząd Morski w Gdyni. Projekt Planu Zagospodarowania Przestrzennego Szczecin and Kamieński Lagoon; Urząd Morski w Gdyni: Gdynia, Poland, 2021. 
76. Urząd Morski w Gdyni. Projekt Planu Zagospodarowania Przestrzennego Zalewu Wiślanego. 2021. Available online: https: //www.umgdy.gov.pl/?cat=303 (accessed on 10 November 2021).

77. Urząd Morski w Gdyni. Szczegółowy Projekt Planu Zagospodarowania Przestrzennego Zatoki Gdańskiej; Urząd Morski w Gdyni: Gdynia, Poland, 2021.

78. Zaucha, J.; Matczak, M. Study of Conditions of Spatial Development of Polish Sea Areas; Maritime Office: Gdynia, Poland, 2016.

79. Zaucha, J.; Kreiner, A. Engagement of stakeholders in the marine/maritime spatial planning process. Mar. Policy 2021, 132, 103394. [CrossRef]

80. Veidemane, K.; Ruskule, A.; Strake, S.; Purina, I.; Aigars, J.; Sprukta, S.; Ustups, D.; Putnis, I.; Klepers, A. Application of the marine ecosystem services approach in the development of the maritime spatial plan of Latvia. Int. J. Biodivers. Sci. Ecosyst. Serv. Manag. 2017, 13, 398-411. [CrossRef]

81. Caune, A.; Kirkovalds, J.; Pužulis, A.; Rijkure, A.; Ungure, I. Stakeholder Involvement in Long-Term Maritime Spatial Planning: Latvian Case. In Development of Future Scenarios for the Shipping and Energy Sectors; Identification of Critical Issues of These Sectors for the Baltic Sea Region Planning Transboundary Discussion Needs: Process and Results; European Commission: Brussels, Belgium, 2017.

82. Bocci, M.; Sangiuliano, S.J.; Sarretta, A.; Ansong, J.O.; Buchanan, B.; Kafas, A.; Caña-Varona, M.; Onyango, V.; Papaioannou, E.; Ramieri, E.; et al. Multi-use of the sea: A wide array of opportunities from site-specific cases across Europe. PLoS ONE 2019, 14, e0215010. [CrossRef] [PubMed]

83. HELCOM Map and Data Service. Available online: http://maps.helcom.fi/website/mapservice/ (accessed on 10 November 2021).

84. Latvian Maritime Spatial Plan Draft, 1. Permitted Use of the Sea in the Gulf of Riga under Latvian Jurisdiction. 2016. Available online: https: / / drive.google.com/file/d/0B9UI5MsfsbRDTmlQMDFzMXBSODQ/view? usp=sharing\&resourcekey=0-87W7 YNmJY_DRDgWzZ82JqA (accessed on 10 November 2021).

85. Latvian Maritime Spatial Plan Draft, 1. Permitted Use of the Sea in the Baltic Proper under Latvian Jurisdiction. 2016. Available online: https: / / drive.google.com/file/d/0B9UI5MsfsbRDZ01EcVc4Q2NuZUk/view?usp=sharing\&resourcekey=0-p1OveqxZz7xzRxk8ucRTQ (accessed on 10 November 2021).

86. FAO. Cabinet of Ministers Regulation No. 631 of 2014 Construction Regulations for Structures in the Internal Waters, Territorial Waters and Exclusive Economic Zone of the Republic of Latvia; FAO: Rome, Italy, 2014.

87. GRASS Project. Output 3.1a: Maps Illustrating MSP Approach to Best Available Sites for Macroalgae Cultivation and Harvesting in the Baltic Sea. 2021. Available online: https://www.submariner-network.eu/grass (accessed on 10 November 2021).

88. Depellegrin, D.; Venier, C.; Kyriazi, Z.; Vassilopoulou, V.; Castellani, C.; Ramieri, E.; Bocci, M.; Fernandez, J.; Barbanti, A. Exploring Multi-Use potentials in the Euro-Mediterranean sea space. Sci. Total Environ. 2019, 653, 612-629. [CrossRef]

89. Christie, N.; Smyth, K.; Barnes, R.; Elliott, M. Co-location of activities and designations: A means of solving or creating problems in marine spatial planning? Mar. Policy 2014, 43, 254-261. [CrossRef]

90. Troell, M.; Joyce, A.; Chopin, T.; Neori, A.; Buschmann, A.H.; Fang, J. Ecological engineering in aquaculture-Potential for integrated multi-trophic aquaculture (IMTA) in marine offshore systems. Aquaculture 2009, 297, 1-9. [CrossRef]

91. Von Thenen, M.; Maar, M.; Hansen, H.S.; Friedland, R.; Schiele, K.S. Applying a combined geospatial and farm scale model to identify suitable locations for mussel farming. Mar. Pollut. Bull. 2020, 156, 111254. [CrossRef] [PubMed]

92. Stuiver, M.; Soma, K.; Koundouri, P.; van den Burg, S.W.K.; Gerritsen, A.; Rockmann, C. The Governance of Multi-Use Platforms at Sea for Energy Production and Aquaculture: Challenges for Policy Makers in European Seas. Sustainability 2016, 8, 333. [CrossRef]

93. Schupp, M.F.; Krause, G.; Onyango, V.; Buck, B.H. Dissecting the offshore wind and mariculture multi-use discourse: A new approach using targeted SWOT analysis. Marit. Stud. 2021, 20, 127-140. [CrossRef]

94. Cabinet of Ministers Regulation No. 53. “Par Jūras Teritoriju Noteikšanu Akvakultūras Darbībai Nepieciešamo Iekārtu Ierīkošanai Un Ekspluatācijai". 2014. Available online: https:/ /likumi.lv/ta/id/264217 (accessed on 10 November 2021).

95. Gómez, T.C.; Lähteenmäki-Uutela, A. European and National Regulations on Seaweed Cultivation and Harvesting. “Growing algae Sustainably in the Baltic Sea" (GRASS) and "Sustainable Cultivation of Seaweed" (SUSCULT) Project Report. 2021. Available online: https:/ /www.submariner-network.eu/images/grass/FINAL-GRASS_GoA_3.2._SYKE_regulation_report.pdf (accessed on 10 November 2021).

96. Bennett, N.J.; Katz, L.; Yadao-Evans, W.; Ahmadia, G.N.; Atkinson, S.; Ban, N.C.; Dawson, N.M.; de Vos, A.; Fitzpatrick, J.; Gill, D.; et al. Advancing Social Equity in and Through Marine Conservation. Front. Mar. Sci. 2021, 8, 994. [CrossRef]

97. Van Hoey, G.; Bastardie, F.; Birchenough, S.; De Backer, A.; Gill, A.; De Koning, S.; Hodgson, S.; Mangi Chai, S.; Steenbergen, J.; Termeer, E.; et al. Overview of the Effects of Offshore Wind Farms on Fisheries and Aquaculture; Publications Office of the European Union: Luxembourg, 2021.

98. Langan, R.; Buck, B.H. Aquaculture Perspective of Multi-Use Sites in The Open Ocean: The Untapped Potential For Marine Resources in The Anthropocene; Springer: Cham, Switzerland, 2017.

99. Westholm, A. Appropriate scale and level in marine spatial planning-Management perspectives in the Baltic Sea. Mar. Policy 2018, 98, 264-270. [CrossRef]

100. Steins, N.A.; Veraart, J.A.; Klostermann, J.E.M.; Poelman, M. Combining offshore wind farms, nature conservation and seafood: Lessons from a Dutch community of practice. Mar. Policy 2021, 126, 104371. [CrossRef] 